\title{
1 EU-China Security Cooperation in Context
}

\author{
Emil F. Kirchner, Thomas Christiansen and \\ Han Dorussen
}

The purpose of this chapter, and of the book as a whole, is to explore EU-China security relations, which have hitherto received scant attention in the writings on EU-China relations. This involves an empirical exercise of studying a number of security dimensions, through a number of heuristic orientations, structural interests and normative considerations. The purpose of these framing devices is to provide common elements of analysis to inform the following empirical chapters, rather than constitute a tight framework leading to systematic application.

EU-China security cooperation may appear tenuous and of little significance when seen next to the substantial amount of trade and other forms of economic cooperation between the two sides. Nevertheless, it is a topic of steadily rising importance, not only because economic and security concerns are becoming increasingly intertwined, but also as nontraditional security threats become more pronounced in international relations. Indeed, aside from economic interdependence, other factors affect the incidence of security cooperation between China and the EU. On the one hand, neither the EU nor China considers the other side as a potential enemy or a military threat - though the nondemocratic nature of the Chinese regime and its maritime territorial disputes continue to be viewed with suspicion by EU policymakers and public opinion (Casarini 2012: 4; Keohane et al. 2014). Instead, both China and the EU support a multipolar international order, and both adopt multilateralism as a key element of their foreign policy, albeit with differences in its practical application.

On the other hand, the EU and China have very different attitudes to key principles of inter-state relations such as state sovereignty, nonintervention and the territorial integrity of states. Furthermore, democratic aspirations and other normative concerns such as the rule of law or good governance matter for the EU in a way that they do not for China. More fundamentally, the fact that the EU is not a state carries with it limitations regarding the cohesion of its security policy, with security and defense policy remaining largely the prerogative of member states. The 
absence of a distinct EU military presence in Asia and the NATO membership of most EU countries diminish EU attractiveness as a genuine (independent) security actor in its dealings with China. While this does not altogether exclude cooperation on military matters between the EU and China, it does put the emphasis more strongly on cooperation in the nontraditional aspects of security, ${ }^{1}$ where both the EU and China may perceive common threats and desire a common response, for example with regard to counterterrorism and climate change.

This chapter seeks to put the complex nature of EU-China security relations into context, both historically and conceptually. It starts by providing a brief overview of the development of EU-China relations in this field over the past decades. Subsequent sections then examine some of the conceptual issues that affect the way in which the EU and China understand (or, as the case may be, misunderstand) one another, before a final section indicates the way in which the substantive chapters of this book address the question of how and to what effect China and the EU are able to cooperate on a range of security matters.

\section{Historical Overview of EU-China Security Relations}

EU-China diplomatic relations have existed for forty years, over which period there have been both setbacks, such as the 1989 Tiananmen Square event, and high points such as the 2003 strategic partnership. A number of important policy papers by both the EU and China have been adopted during this period. Among the more significant ones are the EU-China Trade and Cooperation Agreement (CEU 1985), which provides the fundamental legal agreement between the sides to date, and the EU-China Mature Strategic Partnership (European Commission 2003). China has complemented these sets of agreements with policy papers on the EU in 2003 and 2014 (CMFA 2003, 2014).

The strategic partnership of 2003, which was upgraded in 2010 to include foreign affairs, security matters and global challenges such as climate change and global economic governance, represents the central plank in the EU-China political and security relationship. It has one of the most extensive institutional bases of EU strategic partnerships, and embraces the bilateral level (EU-China), inter-regional contexts (EUASEAN Regional Forum) and global multilateral organizations such as the United Nations and the World Trade Organization (WTO). Further mechanisms of EU-China security cooperation are located in political dialog and the annual EU-China Summit (postponed twice in 2008 and 2011). Moreover, the summit of September 2012 encouraged regular contacts between special representatives and special envoys, holding a 
regular dialog on defense and security policy, increasing training exchanges and organizing the first High-Level Seminar on Defence and Security in 2013. This makes China the fourth country with which the EU has established a dialog on defense and security issues. The EU-China High-Level Strategic Dialogue is an additional channel for security cooperation.

While the main drivers of EU-China relations have undoubtedly been of an economic nature, meaning primarily concerns with trade, investment, monetary and intellectual property issues, the political and security dimensions of the relationship have steadily increased since the mid-1990s. The reasons for this can be found in three interrelated factors. First, as trade and investment between the EU and China has risen in volume, ${ }^{2}$ new political and security challenges have arrived, such as transnational terrorism, nuclear proliferation, environmental degradation and organized crime, which need to be met in the form of cooperative political measures both at bilateral and multilateral levels in order to protect the immense benefits of EU-China trade and investment. Second, as China grapples with domestic political developments (internal democratization developments, and China's "one country, two systems" policy with regard to Taiwan), and as it seeks to play a supportive role in efforts of international peace and stability, China has sought to engage with the EU in a political dialog. China has a positive image of the EU because of its success in overcoming strife and in integrating a huge number of countries peacefully, and because of its contribution to peace and stability in the world. The EU is also not seen as a military threat but rather as a respected and reliable political partner. Third, the EU has had a long-standing desire, going back to its initial engagement with China in the mid-1970s, to extend its values of peaceful coexistence in the form of democratic norms and values to China (Barysch et al. 2005: 1). China, whilst seeking to stifle the import of such values, has a long-standing aim of seeking to counteract the United States' global dominance and sees the EU as an ally in such an attempt. This Chinese perception was particularly prominent after EU divisions in spring 2003 over participation in the United States-led invasion of Iraq, but has since waned somewhat.

Complicating the analysis of past developments - and hence of current and future perspectives - is the presence of contending paradigms through which the nature of EU-China relations can be viewed, with very different results. From a realist perspective, for example, there will be a strong emphasis on the "rise of China" in the context of an emerging multipolar world. In such a view, China, the United States, Russia and the EU are regarded as "poles" that are in potential competition with one another. The debate about China's arrival in Africa, and the dissonance 
that this has created vis-à-vis the EU, is an example of such thinking. From such a realist perspective, with its emphasis on national interests, power and capabilities, the EU-China relationship would appear to have clear limitations.

A different perspective is offered by the focus on identity, ideology and cultural differences, and the way in which these constitute drivers for both cooperation and conflict. While the bloc mentality of the Cold War era may be largely a thing of the past, the EU is still widely seen as being part of "the West" together with the USA, while China remains a country governed by an authoritarian regime, even after the liberalization of its economy and society. The EU and China also have contrasting attitudes to key principles of international relations such as state sovereignty, the universality of fundamental rights and humanitarian intervention. From such a perspective, looking at the way in which images of the "self" and the "other" are being constructed on either side aids understanding of the gaps that remain between China and the EU despite decades of engagement.

However, the arguably dominant vision of EU-China relations is being offered by a liberal-institutionalist perspective, with the focus squarely on the economic dimension and the emphasis on the common interest that both sides share in stability and further development of this relationship. This is not to deny the competitive nature of the respective economies and the resultant differences on issues such as market access, exchangerate manipulation or intellectual property rights. But such differences must be seen within a wider framework of growing trade relations and increasing foreign direct investments on both sides. The sovereign debt crisis in the eurozone, while causing problems for growth in both Europe and China, has actually demonstrated the interdependence of the two economies and reinforced the sense of mutual benefits that come from closer economic cooperation.

\section{Conceptualizing EU-China Security Relations}

The various lenses through which international relations can be viewed, but above all the dominance of the liberal-institutionalist paradigm in the relationship between the EU and China, help to explain the different conceptualizations of security relations. On the whole, EU-China relations - in contrast to US-China relations - are not marked by "balance of power" considerations or the United States' "pivot to Asia," which is to be considered as a rebalancing exercise against Chinese expansion in Asia (White House 2013). However, even though Chinese relations with the EU are not seen in the context of the "great power" rivalry that is 
often detected in its relations with the United States (Shambaugh 2012; Dorussen and Kirchner 2014; Mearsheimer 2014), the EU and China might still be perceived as having hegemonic tendencies in the pursuance of their respective interests and value considerations in the regional and international arena (Buzan and Wæver 2003; Katzenstein 2005). As both have developed considerable economic power, they are forced to secure the fruits of their economic success through a growing number of bilateral and multilateral cooperative security arrangements.

Observers are divided as to whether China's rise as an economic and political power will result in it becoming a responsible stakeholder in the international system, or whether it will end up pursuing a revisionist rather than a status quo policy (on the former, see Van der Putten and Chu 2011; Foot 2012; Kahler 2013; on the latter see Ikenberry 2011; Johnston 2013). Either of these outcomes of Chinese policy will have repercussions on EU policies, whose general aims are supportive of the existing international system while pressing for occasional reforms. Consequently, the question as to whether the EU and China engage with each other cooperatively in the security domain or pursue different and possibly even conflicting - strategies requires thorough empirical research across a number of dimensions - as provided in the contributions to this volume.

\section{Key Concepts in the Analysis of EU-China Security Relations}

This exercise will be guided by the use of a number of key concepts that serve as heuristic tools for subsequent empirical analyses that are linked in their practical application. Convergence (and its negative counterpart, divergence) is defined in this context as the degree of policy conformity the EU and China are able (or unable) to achieve in a given security dimension. Cooperation is defined as the degree of actual security cooperation between the EU and China, whether in the shape of formal agreements or of joint actions (involving either material resources or firm commitments to joint standards) in each of the security dimensions under investigation. These two heuristic devices are to some extent interrelated in that changes in the (geopolitical) structural domain may affect changes in national interests, while changing interests can impact on the way norms are applied in the field of EU-China security cooperation. Accordingly, we may observe divergence or convergence between China and the EU. China and the EU may agree (or disagree) which security threats they find more salient and on how to respond to perceived threats. For example, as China has become more interdependent in the world economy, its economic security concerns have become more 
similar to the EU's understanding, with China and the EU advocating a similar multilateral approach. Another example of such convergence is the observation that nontraditional security threats have become more salient for China as well as for the EU in the post-Cold War era. These structural changes have led to at least minimal convergence in the way the EU and China define threat perceptions and norms regulating policy responses. This, in turn, has opened up a space for collaboration, however minimally defined.

However, whilst it is plausible to assume that there is a strong link between the existence of policy conformity and levels of cooperation, the possibility that cooperative arrangements or joint actions can arise independent of any such link cannot be discounted altogether: cooperation might occur spontaneously as a consequence of exogenous events such as natural disasters, something that must remain a potential scenario to be established by empirical research.

\section{Assessing Convergence and Cooperation}

The discussion of convergence and cooperation as key concepts in the analysis of security relations raises questions about how to measure developments in this respect. Therefore it is necessary to elaborate here briefly on the specific criteria used in this study. Convergence is assessed by the following two factors: first, the extent to which uniform positions exist within the EU and China on the perception of threats and the relevant responses with regard to ten specific security dimensions; and second, the extent to which (dis)agreement exists on issues of sovereignty or nonintervention in a given security dimension and, therefore, the extent to which they can act as barriers to convergence. Rather than merely bringing to light the similarities or dissimilarities in the assessment of threat perceptions and responses, which would tend to portray a static view, the aim is to explore the dynamic element. In other words, it is not enough to simply state that sovereignty or noninterference principles are an issue, but to explore whether, over time, changes have taken place and/or the force of the argument for convergence has either weakened or strengthened. This involves an application of the heuristic elements outlined below in the shape of structure, interests and norms.

Cooperation is assessed essentially in three different ways. First, the extent to which the EU and China have engaged in joint agreements of actions either at the bilateral or the multilateral level. Joint agreements can be in the form of summit declarations or the adoption (signing and ratifying) by both partners of, for example, UN conventions. But it will be important to distinguish the extent to which cooperation is merely at the 
level of "intentions" (rhetoric) or involves a number of actual joint actions; or put differently, whether the prospects for cooperation between the EU and China remain at the level of discourse rather than practice. Joint actions can, at the low end, take the form of information exchanges on counterterrorism activities, organized crime or cyber security, and, at the high end, the joint antipiracy maritime operations between the EU and China along the coast of Somalia. With regard to joint actions, it will be important to examine: the type, frequency or length of action; the material or personnel sources involved in these actions; the temporal or lasting effect which can be attributed to them; and the springboard or multiplier implication which can be associated with them. It might also be interesting to establish whether cooperation is more pronounced at the bilateral rather than at the multilateral level, and whether there is a strong relationship in performance between these two levels or none at all. Second, cooperation is studied through the extent to which barriers to EU-China cooperation exist. The concern here will be with existing obstacles within the EU (among EU institutions and/or between EU institutions and member states) to forge common positions, and maneuvers by China to divide or undermine EU consensus in selectively dealing with EU institutions (the Council or Commission) and individual EU member states. This will also include consideration of the United States' role in either promoting or hindering EU-China security cooperation. ${ }^{3}$ Finally, a third criteria is the extent to which cooperation is in line with the levels of convergence or divergence noted earlier in the analysis, or exists separately, for example, as a spontaneous - possibly one-off response to events such as natural disasters or pandemics.

In the following, a number or pertinent issues relating to the chosen unit of analysis are discussed. This will be followed by a treatment of the theoretical and conceptual orientation of the chapter and how the adopted conceptual framework will be applied in the book.

\section{The Levels of Analysis Problem in Studying EU-China Relations}

The choice to focus in this analysis on EU-China security relations, rather than on the security relations of the EU's member states with China, or else on what is sometimes loosely referred to as "Sino-European" security relations, may require some explanation. First of all, this volume is intended as a contribution to the literature on the EU's external relations and in particular on its evolving role as a security actor. From modest beginnings, the EU has developed a wide-ranging security policy, and how this shapes up in relations with China - not a traditional ally yet one of its strategic partners - is of considerable scholarly interest and political relevance. 
The book does recognize that, undoubtedly, individual EU member states such as, for example, France and the United Kingdom, have a longer and more involved security engagement with China than the EU does. This greater involvement is the result of a combination of such factors as their status as nuclear powers and permanent members of the United Nations Security Council, the experience of small-scale military personnel visits and exchanges, and long-standing bilateral strategic partnerships with China. Such bilateral security relations may provide interesting - even important - insights, but the analysis of those respective bilateral security relations would not provide a full account of what EU-China security relations entail in scope or degree.

Most importantly, focusing on the member states rather than on the EU and its common institutions and policies would downplay - and risks neglecting - the host of instances where the EU has demonstrated that it does indeed constitute a security actor in its own right when dealing with China. Examples are the antipiracy operation along the coast of Somalia, climate change negotiations, counterterrorism measures and the arms embargo issue. Consequently, the choice made in this book has been to focus predominantly on the European level as the main level of analysis while incorporating, where appropriate, the role of member states when examining the specific security dimensions that have been chosen for the analysis of EUChina security relations. In line with this choice, the following section turns to the conceptual orientation of EU-China political and security relations.

\section{Heuristic Devices Informing the Analysis: Structure, Interests and Norms}

In line with the basic premise of this chapter, security cooperation is considered to be affected by similar or converging EU and Chinese views with regard to threat perceptions and relevant responses. Depending on the degree of convergence in views within a given security dimension, cooperation may be either enhanced or hindered. Furthermore, the degree of policy conformity or converging views which exists in a certain security dimension is influenced by changes in geopolitical-economic structure, interests and norms. These three aspects are linked to some extent, in that changes in the (geo-)structural domain can affect changes in national interests, and changes in interest formation can affect change in the way norms are applied in the field of EU-China security cooperation. The effects of these changes can either promote or impede what Simmons et al. (2006) call "interdependent decision-making" where policy choices of one country are shaped by the choices of others, in this case decision-making and joint actions in the field of EU-China security 
cooperation. The following will explore in more detail the three aspects which are seen to affect EU-China security cooperation in this manner.

\section{Structural Factors}

Both the EU and China have undergone significant changes as economic and political actors on the international scene. The rise of China as anportant economic and political actor on the international scene began in the early 1990s, with Beijing's drive to expand its bilateral and multilateral links in order to foster rapid economic growth based on economic reform and opening up after the rejection of the rules of the international system by Mao. The emergence of the EU's economic strength predates that of China. Partly because of representing the second-largest economic partnership globally, ${ }^{4}$ and partly because of dependency on external trade, both the EU and China have considerable interest in ensuring that international trade routes are secured (Reiterer 2013). Moreover, to improve their prosperity, both need an open trading system and access to energy sources and raw materials. The link between economic interaction and security, at the bilateral (EU-China) and multilateral levels, is hence a significant factor in EU-China relations, and one of the main reasons why the economic dimension of security is the subject of a distinct chapter in this study.

A second structural change with implications for EU-China security relations relates to change in the nature of security threats. While the Cold War was dominated by an overlay of a global conflict structure, the post-Cold War security landscape has increasingly been dominated by regional security interactions (Buzan and Wæver 2003) and regional integration dynamics (Hettne 2003). A core concern in this respect is the perceived rise of sub-system violent conflicts, often discussed under the header of "new wars" (Kaldor 1999; Münkler 2005). Generally, nontraditional security threats have risen in importance not only in Europe but also in Asia, including climate change, the threat of viral pandemics, the pursuit of food and energy security as well as the effects of regional conflicts (Caballero-Anthony and Cook 2013). As a consequence, nontraditional aspects of security have become more prominent in EU-China security relations. This factor is reflected in the selection of the security dimensions of this study, where stress is given to sub-system conflicts and nontraditional security threats.

\section{The Role of National Interests}

National interest is affected by geo-economic or political changes and by domestic or internal conditions. In terms of domestic or internal 
conditions, both the EU and China seek to influence and shape their external security environment in ways that best benefit their respective interests. Callahan (2012) goes as far as to link China's national security with its nationalist insecurities. In part this is due to the fact that China is still in a state-building or developing mode. In terms of geo-economic or political terms, China's aspiration to "great power" status contrasts clearly with the rule-based effective multilateralism interests espoused by the EU. Whereas China's interests are primarily based on national defense and security, and on territorial protection, the EU includes milieu security interests in its defense and security calculus. There is also a contrast between the more "other"-oriented approach of the EU and the more "self-centered" worldview of China. However, dissimilar and similar interests are sometimes not far apart. This can be seen with regard to Central Asia, where the EU and China are competitors in terms of seeking access to Central Asian gas and oil, but are partners in terms of striving to reduce Russian influence. While the EU and China pursue similar aims with regard to the promotion of multipolarity, they differ over the extent to which this should be used as a counterweight to US global dominance. Both are supporters of multilateralism and the role of international organizations, but they differ on the extent to which multilateralism should be applied and the status quo of international organizations be observed. While both seek international stability, they also see each other in part as undermining this stability. The EU sees Chinese maritime border disputes as affecting security in the Asia-Pacific, whereas China perceives the EU's engagement in the Ukraine (together with that of NATO) as contributing to the instability in the Eurasia region.

Generally, EU efforts to provide incentives for achieving converging views on security between the EU and China are limited and, to the extent to which they exist, they are primarily confined to the nontraditional aspects of security. In contrast to its ability to set conditions for countries aspiring to EU membership in terms of economic and political adjustments, for countries benefiting from EU aid and cooperation agreements (for example, those in Africa, the Pacific and Caribbean) or for the granting of trade privileges, with few exceptions no such mechanisms are at work in EU-China security relations. Among the exceptions is the period before and around 2000, just before China became a member of the WTO, when the EU was able to exert pressure for Chinese economic and political reforms. Although the EU provides substantial aid and technical assistance, as well as programs which promote greater democratization, these do not seem to affect Chinese security policies significantly. What seems to affect Chinese security outlook more directly is its attempt to emulate the EU's peaceful development, particularly as 
expressed in the EU's civilian power concept. Such an association can also be used by China to justify that its rise in the international arena will be similarly peaceful.

\section{The Power of Ideas and Norms}

In a mutually constructive way, ideas and norms can impact on the identity of national interests of the involved actors. They can also help to establish or strengthen the mutual understanding and mutual trust between the EU and China. This can be illustrated in a number of examples. Not only does China explicate the EU as a model in terms of international standing, China also sees virtues in the confederal structure of the EU. Both the EU and China uphold the principle of peaceful coexistence and emphasize equality, mutual trust, respect and cooperation. Both see each other more as partners than as enemies. The same expectation cannot be said to hold in China's relations with, for example, Japan or the United States.

Differences exist regarding the extent to which consensus through consultation and the peaceful settlement of disputes is to be achieved. This issue links strongly with the application of the sovereignty and nonintervention principles. Whereas China applies a strict adherence to these principles, the EU does not rule out military intervention in cases of "failed state" scenarios, that is, where states fail to adequately protect their citizens, or where looming humanitarian disaster requires intervention, for example, in the western Balkans and parts of Africa. In contrast to China, the EU also attaches conditionality to its trade agreements and development cooperation. However, those principled differences are not always as stark as they appear. For example, China has deviated from its strict adherence to nonintervention, such as when permitting NATO action in the Libyan conflict of 2011. At the same time, China's assertive maritime behavior in the South and East China Seas, which can be seen as a deviation from China's declared policy of the "peaceful settlement of disputes," demonstrates that both the EU and China are prepared to exercise a mixture of persuasive and coercive elements of statecraft.

Security cooperation between the EU and China, involving values and norms, works through a mix of socialization processes and social learning. It is widely accepted that the EU seeks to influence other regional integration processes and that, in reverse, other regional organizations are attracted to the European integration experience. In the Chinese case, there has been considerably less effort to pursue a comprehensive engagement with the outside world. However, China has consistently advanced its principles of peaceful coexistence, based on equality, mutual 
trust, respect for sovereignty and cooperation. Since 2010 it has sought to give greater voice abroad to these principles through the establishment of an increasing number of Confucius Institutes. In any case, these efforts at external "image creation" are a conflation of norms and interests, and reflect hegemonic tendencies in that both the EU and China seek to pursue their respective interests and value considerations in the regional and international arena.

Socialization processes and social learning links with knowledge transfer. The expectation is that knowledge transfer between the EU and China takes place more in some security dimensions than in others. Knowledge transfer from the EU to China is likely to be practiced in the fields of climate change, economic security, infectious diseases and food safety, but less so on aspects which touch more explicitly on human rights. Notwithstanding the nearly twenty years of existence of the EU-China Human Rights Dialogue, differences appear as strong as ever, with China emphasizing the collective security of the people together with a state-centric view, and the EU prioritizing the security of the individual and the need to intervene in cases where states fail to protect their citizens from harm. Equally, deep-seated (cultural) differences over ideas, principles and norms in cyber security impede knowledge transfer in both directions between the EU and China. Obviously, these are suppositions at this stage and will need to undergo careful scrutiny in the subsequent chapters.

The derived heuristic devices of structure, interests and norms will inform the empirical analysis of this study by providing guidance as to why certain levels of convergence or divergence appear between the EU and China in the assessment of threat perception and relevant responses. An understanding of these three devices provides important information about the extent to which sovereignty principles, especially those of China, are upheld or shifting in EU-China security relations. Knowledge of these heuristic devices and key issues will be instrumental in assessing levels of convergence or divergence. The results of these levels will then act as a benchmark for the assessment of actual EU-China security cooperation.

\section{Overview of the Contributions to this Volume}

The substantive chapters covering the chosen security dimensions are structured along the lines of five core themes arising from the previous discussion:

- threat perceptions

- response to threats

- the degree of convergence/divergence on threat perceptions and response 
- the incidence of cooperation at the bilateral level

- cooperation at the multilateral level.

After having briefly explored the development of the particular security dimension, authors examine the threat perceptions and policy response preferences of both the EU and China in the respective security dimension. This will also involve an examination of the existing barriers to convergence by considering the implications of changes in terms of (geopolitical) structure, interests and norms. In a second step, the analysis identifies the degree to which policy convergence in threat perceptions and response exists between the EU and China. The presence or absence of policy convergence will then be related to an assessment of the degree of cooperation that the EU and China have undertaken in a given security dimension either at the bilateral or the multilateral level. Attention will also be paid to whether joint cooperative actions in the security field occur in the absence of convergence, for example, through spontaneous joint actions in response to natural disasters. While this step will examine the evidence for actual cooperation, or potential thereof, it will also examine the extent to which barriers exist both within the EU (problems of cohesion) and between the EU and China (for example, attempts by China to undermine EU cohesion, or the United States' efforts to influence EU policy).

The book covers a range of traditional and nontraditional security dimensions which are examined by teams of authors along these lines. Specifically, the ten security dimensions that have been selected for this analysis are:

- military security

- regional security

- nuclear proliferation

- terrorism and organized crime

- climate and energy security

- human security

- civil protection

- cyber security

- economic security

- migration and immigration.

The choice to focus on these security dimensions is justified in terms of the explicit reference that both Chinese official policy papers as well as key EU documents such the 2003 European Security Strategy (ESS) (CEU 2003) and the 2008 Implementation Report of the ESS (CEU 2008) make to these particular areas.

The ten security dimensions have also been selected in part because of the expectation that they induce different cooperation characteristics. 
One assumption here is that there may be a variation between higher and lower levels of cooperation across these areas. Medium to high levels of cooperation might be expected for the chapters on climate change and energy security (Bo, Biedenkopf and Chen) and on economic security (Geeraerts and Huang). These are areas where, despite differences over sovereignty issues, either the common perception of threats has risen over a considerable period of time or where international norms, collaboration or regulatory arrangements have promoted the adoption of similar policy approaches between the EU and China (for example, ensuring that international trade routes are secured, or that measures are adopted in response to climate change). In contrast, low levels of cooperation can be expected for chapters dealing with human security (Harnisch and $\mathrm{He}$ ), cyber security (Bersick, Christou and Shen), military security (Duke and Wong) and migration (Chou, van Dongen and Koff). These security dimensions are more closely associated with deep-seated EUChina differences over sovereignty (rooted in historical legacies, identity factors, developmental aspects and so on), differences in threat perceptions (for example, China's internal floating population and emigration concerns versus the EU's security concern with external migration and immigration) or the belated arrival of EU-China security relations (for example, cyber security). As it developed as a supranational (EU) or national (China) policy area, civil protection (Dorussen, Jin and Fanoulis) has also recently become part of EU-China security relations. Here, there has, however, been more progress. In between high and low levels of EU-China security relations are the chapters associated with dimensions of nuclear proliferation (Casarini and Song) and regional security cooperation (Diez, Scherwitz and Tan). While the EU and China have substantial levels of common threat perceptions on these two security dimensions, it is expected that different interests (for example, China's approach towards North Korea or China's more assertive behavior in the East and South China Seas) undermine higher levels of cooperation.

\section{Conclusion}

Since 2003 there has been increasing understanding between the EU and China that security cooperation needs to complement the economic and political dialog between the two countries. How far this understanding translates into practice, which aspects of security benefit more and which less, and the underlying reasons for the occurrence or absence of cooperation raise theoretical and conceptual issues, and require empirical examination. From a theoretical perspective, EU-China security relations have traditionally been assessed from such approaches as realism and liberal 
internationalism. However, as indicated above, neither of these approaches by themselves provides an appropriate framework for assessing EUChina security cooperation across a spectrum of security dimensions. It appears more appropriate to consider changes in the geo-economic and political context, changes in interest formation and practice, and changes in normative behavior. Changes in the structure of the international system will affect how China and the EU define their interests and their normative understanding of appropriate actions. Consideration of these aspects will inform, rather than structure, the analysis in the subsequent substantive chapters. A systematic overview of the findings across the various policy domains will be provided in the concluding chapter.

Different identity considerations and approaches to key issues such as sovereignty and noninterference have important implications for the extent to which the EU and China converge or diverge in policy preferences to perceived security threats. In turn, together with levels of convergence or divergence in threat perception and relevant responses, they affect levels of cooperation (intensity, frequency and resources involved) or noncooperation in EU-China security relations. How far this effect occurs, and whether it occurs equally across a number of security dimensions, is largely an empirical question. An attempt has been made in this chapter to explore the empirical terrain of EU-China security relations, but a much more careful analysis of this will be undertaken in subsequent chapters.

The following ten chapters provide a mapping exercise or inventory of different security dimensions, showing in which aspects of EU security cooperation there is greater convergence or cooperation, and in which there is less. Expectations are that such an exercise will provide a more differentiated picture of the various facets of security policy than those often associated with a one-dimensional (for example, military, environmental or cyber security) treatment of EU-China security relations.

\section{NOTES}

1 Although it is difficult in practice to make a clear distinction between traditional and nontraditional security, we link traditional security with military security, nuclear proliferation and regional security. Following Williams (2013), we deem these three aspects as being concerned with the interplay between the armed offensive and defensive capabilities of states and states' perceptions of each other's intentions. Nontraditional security in our conception deals with the political, economic, societal and environmental security of states where issues of organizational stability, access to resources, the preservation of cultural traits and environmental sustainability are a concern. Among the aspects which have these nontraditional security characteristics are terrorism and 
organized crime, climate change and energy security, economic security and human security. For further details on the subject, see Buzan et al. (1998) and Williams (2013).

2 Bilateral trade in goods rose from $€ 4$ billion in 1978 to $€ 467$ billion in 2014 (see Chapter 10, this volume).

3 Authors of individual chapters were asked to include, where relevant, a reflection on the role played by the United States in their particular area of concern. For further treatment of the United States' role in EU-China security relations, see the Chapter 12 (this volume).

4 The economy of the EU represents $€ 12.6$ trillion and that of China $€ 4.6$ trillion; the United States represents $€ 11.3$ trillion (Barroso 2013). China has the world's largest foreign reserves at US\$3.95 trillion as of the first quarter of 2014 (Noble 2014).

\section{REFERENCES}

Barroso, J. M. D. 2013. "The Best Is Yet to Come: Past, Present and Future of the EU-Hong Kong Relationship." Document SPEECH/13/966. Available at: http://europa.eu/rapid/press-release_SPEECH-13-966_en.htm (accessed April 30, 2016).

Barysch, K., Grant, C. and Leonard, M. 2005. "Embracing the Dragon:The EU's Partnership with China." Centre for European Reform. Available at: www. cer.org.uk/sites/default/files/publications/attachments/pdf/2011/p_610_ dragon_partnership-910.pdf (accessed April 30, 2016).

Buzan, B. and Wæver, O. 2003. Regions and Powers: The Structure of International Security. Cambridge: Cambridge University Press.

Buzan, B., Wæver, O. and de Wilde, J. 1998. Security: A New Framework for Analysis. Boulder, CO: Lynne Rienner.

Caballero-Anthony, M. and Cook, A. (eds.). 2013. Non-Traditional Security in Asia: Issues, Challenges and Framework for Action. Singapore: Institute of Southeast Asian Studies.

Callahan, W. 2012. China: The Pessoptimist Nation. Oxford: Oxford University Press.

Casarini, N. 2012. "EU Foreign Policy in the Asia Pacific: Striking the Right Balance between the US, China and ASEAN." European Union Institute for Security Studies. Available at: www.iss.europa.eu/publications/detail/article/ eu-foreign-policy-in-the-asia-pacific-striking-the-right-balance-betweenthe-us-china-and-asean/ (accessed April 30, 2016).

CEU (Council of the European Union). 1985. "Council Regulation Concerning the Conclusion of a Trade and Economic Cooperation Agreement between the European Economic Community and the People's Republic Of China." Document 2616/85. Available at: http://eur-lex.europa.eu/legal-content/EN/ TXT/PDF/?uri=OJ:L:1985:250:FULL\&from=EN (accessed May 9, 2016).

CEU. 2003. "A Secure Europe in a Better World: European Security Strategy." Document COM (2003), 533 final. Available at: www.consilium.europa.eu/ uedocs/cmsUpload/78367.pdf (accessed February 27, 2014).

CEU. 2008. Reporting on the Implementation of the European Security Strategy: Providing Security in a Changing World." Available at: www. 
consilium.europa.eu/ueDocs/cms_Data/docs/pressdata/EN/reports/ 104630.pdf (accessed January 24, 2015).

CMFA (Chinese Ministry of Foreign Affairs). 2003. "China's EU Policy Paper." Available at: www.fmprc.gov.cn/eng/topics/ceupp/t27708.htm (accessed January 28, 2013).

CMFA. 2014. China's Policy Paper on the EU: Deepen the China-EU Comprehensive Strategic Partnership for Mutual Benefit andWin-Win Cooperation.” Available at: www.fmprc.gov.cn/mfa_eng/wjdt_665385/wjzcs/t1143406. shtml (accessed January 24, 2015).

Dorussen, H. and Kirchner, E. 2014. "Better a Good Neighbor than a Distant Friend: The Scope and Impact of Regional Security Organizations," International Relations of the Asia-Pacific 14(1): 117-46.

European Commission. 2003. "A Maturing Partnership: Shared Interests and Challenges in EU-China Relations." Document COM (2003) 533. Available at: http://eur-lex.europa.eu/legal-content/EN/TXT/HTML/?uri=URIS ERV:r14207\&from=EN (accessed May 9, 2016).

Foot, R. 2012. "US-China Interactions in Global Governance and International Organizations," in D. Shambaugh (ed.), The Tangled Titans: The United States and China. Lanham, MD: Rowman and Littlefield, 315-46.

Hettne, B. 2003. "Security Regionalism in Europe and South Asia," in J. Hentz and M. Boas (eds.), New and Critical Security and Regionalism: Beyond the Nation State. Burlington, VT: Ashgate, 149-66.

Ikenberry, G. J. 2011. “America's Challenge: The Rise of China and the Future of Liberal International Order.” New American Foundation. Available at: http://newamerica.net/publications/policy/america_s_challenge (accessed November 4, 2014).

Johnston, A. I. 2013. "How New and Assertive Is China's New Assertiveness?" International Security 37(4): 7-48.

Kahler, M. 2013. "Rising Powers and Global Governance: Negotiating Change in a Resilient Status Quo," International Affairs 89(3): 711-29.

Kaldor, M. 1999. New and Old Wars: Organized Violence in a Global Era. Stanford: Stanford University Press.

Katzenstein, P. 2005. A World of Regions: Asia and Europe in the American Imperium. Ithaca, NY: Cornell University Press.

Keohane, D., Lehne, S., Speck, U. and Techlau, J. 2014. "A New Ambition for Europe: A Memo to the European Union Foreign Policy Chief." Carnegie Europe. Available at: http://ceip.org/1wDL5bw (accessed January 29, 2015).

Mearsheimer, J. J. 2014. The Tragedy of Great Power Politics, updated edn. New York: Norton.

Münkler, H. 2005. The New Wars. Oxford: Polity Press.

Noble, J. 2014. “China's Foreign Exchange Reserves Near Record \$4tn," Financial Times, April 15. Available at: www.ft.com/cms/s/0/4768bd3c-c461-11e38dd4-00144feabdc0.html (accessed September 7, 2015).

Reiterer, M. 2013. "The View from the EU," in N. Casarini (ed.), "BrusselsBeijing: Changing the Game?" Report No. 14, European Union Institute for Security Studies. Available at: www.iss.europa.eu/uploads/media/Report_14.pdf (accessed April 30, 2016). 
Shambaugh, D. (ed.). 2012. The Tangled Titans: The United States and China. Lanham, MD: Rowman and Littlefield.

Simmons, B., Dobbin, F. and Garrett, G. 2006. "Introduction:The International Diffusion of Liberalism," International Organization 60(4): 781-810.

Van der Putten, F.-P. and Chu, S. 2011. "Conclusion," in F.-P. Van der Putten and S. Chu (eds.), China, Europe and International Security: Interests, Roles and Prospects. London: Routledge, 195-201.

White House. 2013. "Resourcing the Rebalance toward the Asia-Pacific Region." Available at: www.whitehouse.gov/blog/2013/04/12/resourcing-rebalancetoward-asia-pacific-region (accessed October 27, 2014).

Williams, P. (ed.). 2013. Security Studies: An Introduction. London: Routledge. 